\title{
NEW RARE PLANT FINDS ALONG THE SOUTH SASKATCHEWAN RIVER VALLEY
}

DIANA BIZECKI ROBSON, 811 Avenue E North, Saskatoon, SK S7L 1S7

While conducting research for a Master's thesis project on rare plants in southwestern Saskatchewan, I discovered nine new rare plant populations along the South Saskatchewan River, southwest of the Gardiner Dam. One new population of False Buffalo Grass (Munroa squarrosa), three new populations of Western Hawk's-beard (Crepis occidentalis) and five new populations of Rush

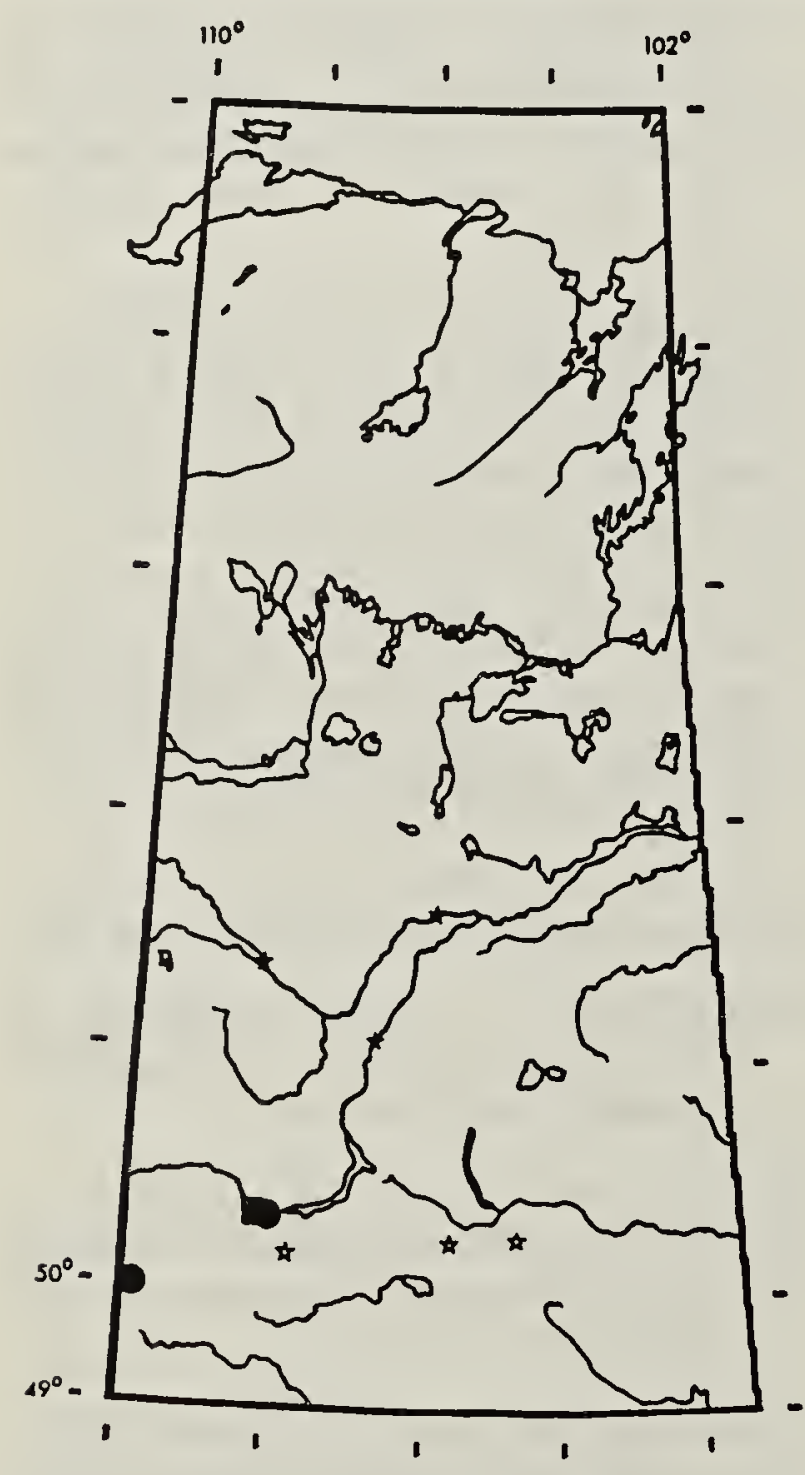

Figure 1. Distribution of False Buffalo Grass (Munroa squarrosa) in Saskatchewan.

- = previous populations

= new population
Pink (Stephanomeria runcinata) were found. Verified voucher specimens are on file at the W.P. Fraser Herbarium, University of Saskatchewan, Saskatoon, SK.

\section{False Buffalo Grass}

This population represents the third documented discovery of this plant in the province (Figure 1). The two other populations are in Saskatchewan Landing Provincial Park, and $3 \mathrm{~km}$ southwest of Hatton. False Buffalo Grass is a low-lying, tufted annual grass (Figure 2). ${ }^{1}$ The leaf margins are scabrous (rough due to small hairs) and white banded, and the collar is covered with long soft hairs. 'The plants were found on 13 July 1996 approximately 15 miles $(9.4 \mathrm{~km})$ southwest of Kyle (SW1/4 S9 T20 R16 W3). Forty-two live individuals and thirty dead ones were found along a gravel road about 200 $\mathrm{m}$ north of the river. The dead plants were killed when a road grader came by a week or two earlier. Numerous other low, weedy plants occurred in the same habitat.

\section{Western Hawk's-beard}

Western Hawk's-beard is a perennial, insect-pollinated composite (Figure 3 ). This species looks somewhat similar to the Common Dandelion (Taraxacum officinale) with yellow rayed flowers and a basal rosette of toothed leaves. ${ }^{1}$ However, Western Hawk's-beard produces several heads on a stem as opposed to dandelions which have solitary heads.' 


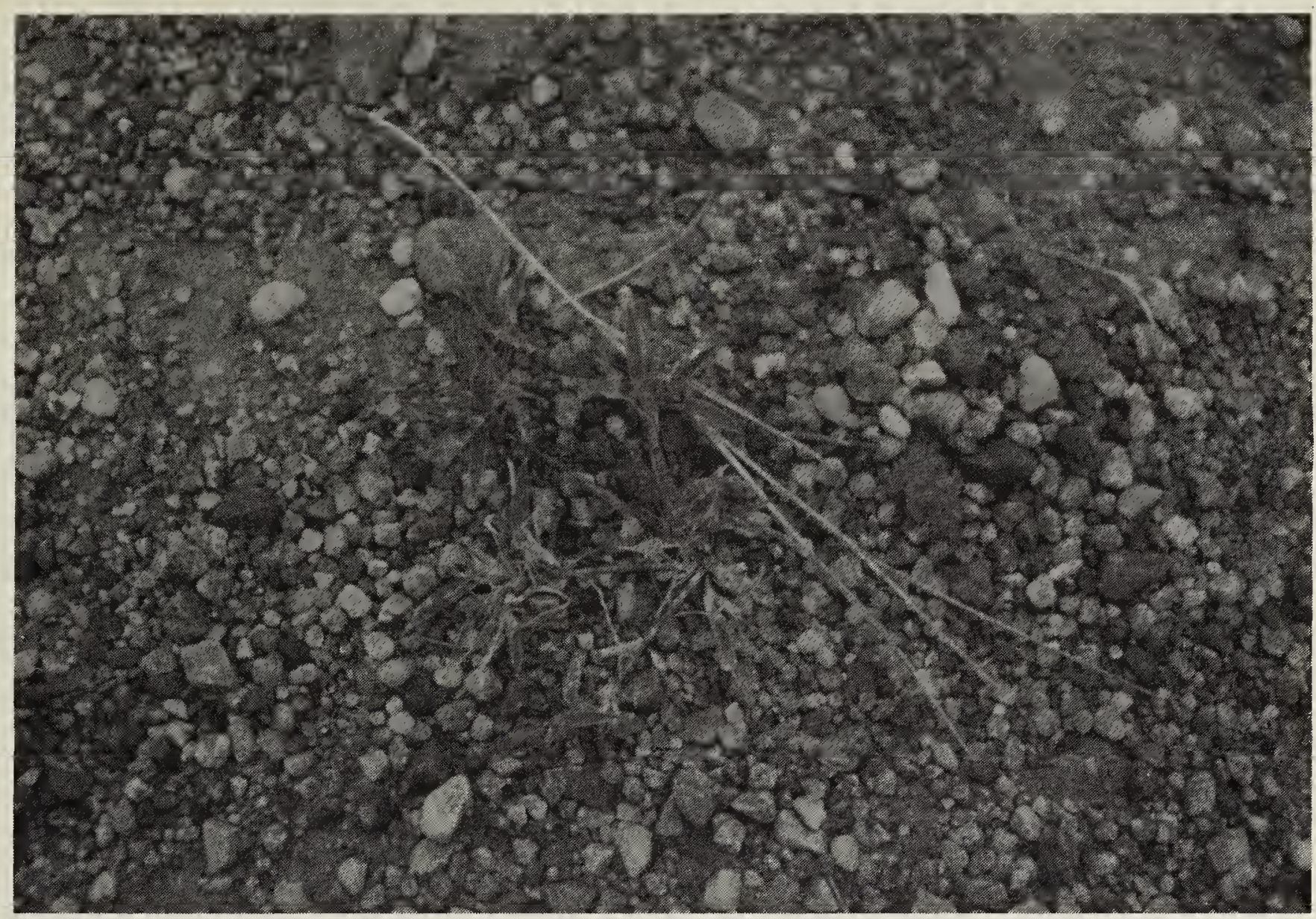

Figure 2. False Buffalo Grass (Munroa squarrosa).

As well, the leaves of Western Hawk's-beard are densely grey, soft and hairy, while those of the dandelion are hairless. ${ }^{1}$ This species is found along the Frenchman and
South Saskatchewan River valleys (Figure 4).

The first new population of Western Hawk's-beard was found on 31

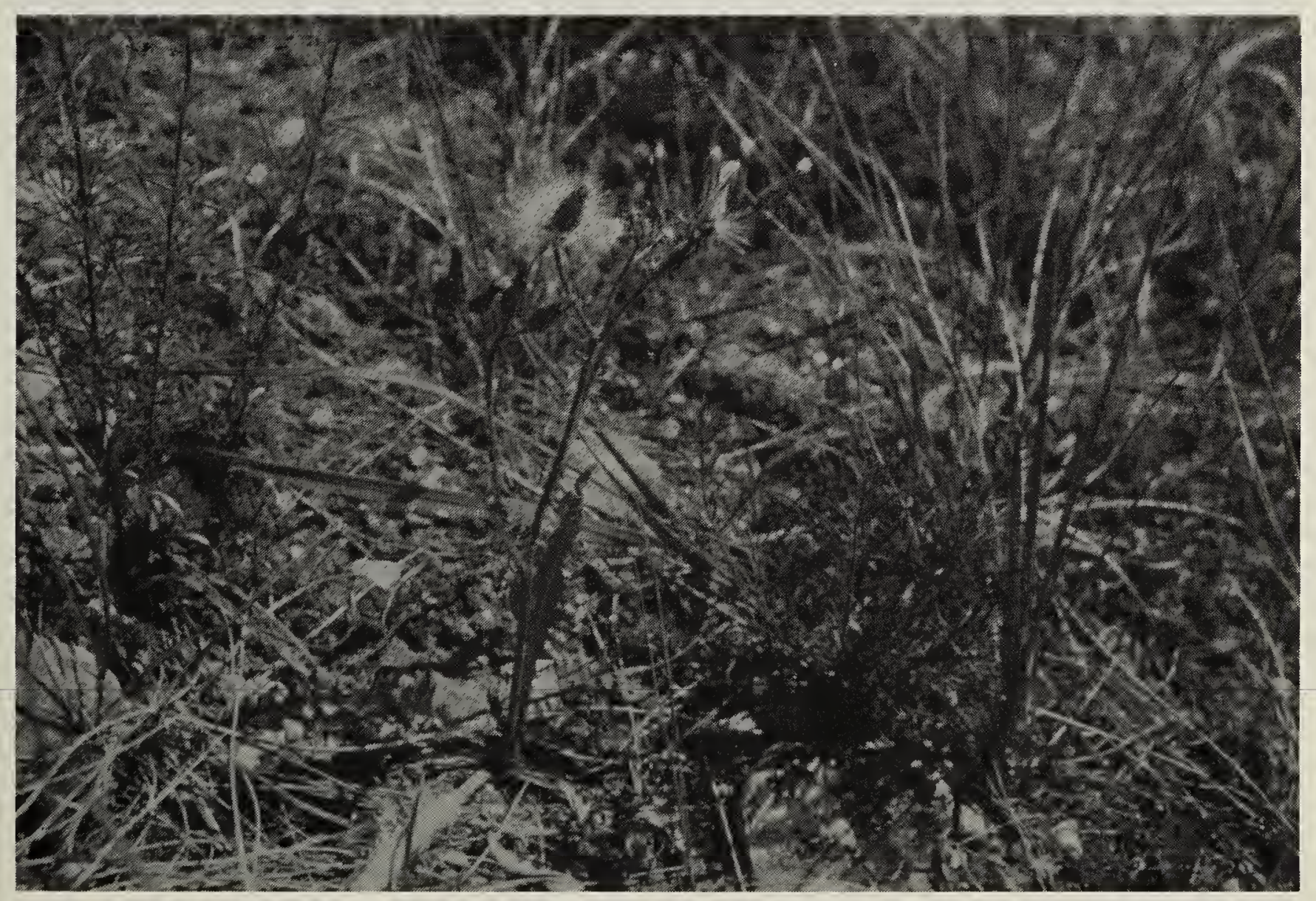

Figure 3. Western Hawk's-beard (Crepis occidentalis). 


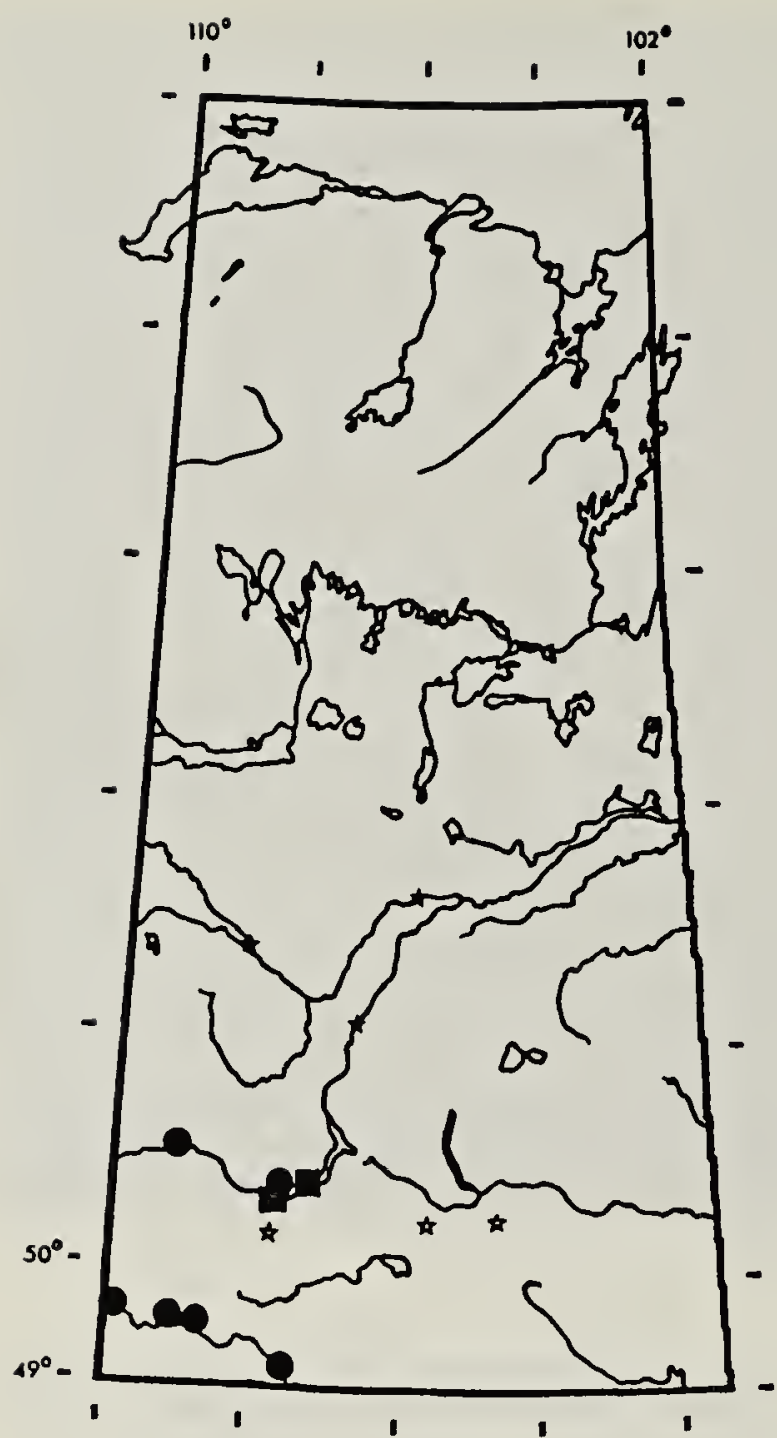

Figure 4. Distribution of Western Hawks-beard (Crepis occidentalis) in Saskatchewan.

- = previous populations

- new population

May 1995, south of the University of Saskatchewan's Matador Research station about 20 miles (32 km) southeast of Kyle. Seventeen individuals were found on the south-facing, loamy side slope of a hill, near a small juniper-covered ravine. The site is $40 \mathrm{~m}$ southeast of the corner fence of S10 T20 R13 W3 of the Matador preserve. Interestingly enough, 20 Rush Pink plants were found in the exact same location.

When Saskatchewan Landing Provincial Park was visited on 19 July 1995, a second population of Western Hawk's-beard and a population of Rush Pink were discovered. A voucher specimen of Western Hawk's-beard was not collected due to the small population size; a photo-

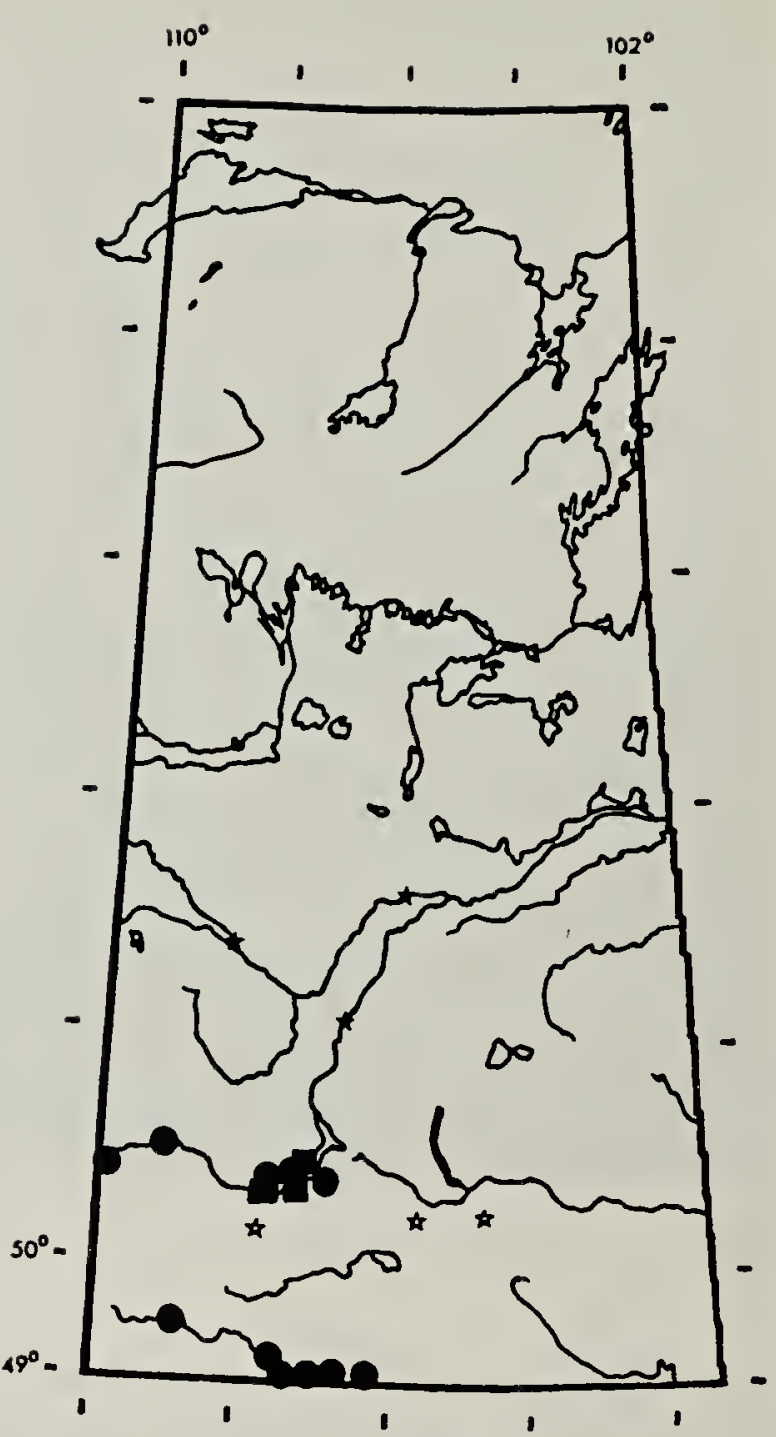

Figure 5. Distribution of Rush Pink (Stephanomeria runcinata) in Saskatchewan.

- = previous populations

- new population

graph was taken instead. Neither of these plants had been found in the park before. Western Hawk's-beard was discovered in a moist, junipercovered draw above an old road. Rush Pink was found at four different park locations on eroded, silty, south-facing slopes nearly bare of vegetation. In total, 28 Western Hawk's-beard plants and 800 Rush Pink plants were counted. More populations of these species are probably present in the park as many areas are still unexplored by botanists.

The third population of Western Hawk's-beard was located 11 miles $(17.6 \mathrm{~km})$ southeast of Beechy (S31 T20 R10 W3) on 22 May 1996. The habitat was a partly eroding, dry, 
southern slope along a coulee. The soil texture was sandy loam. About 330 individual plants were estimated to occur in this area. As well, approximately 200 Rush Pink plants were found in the same habitat.

\section{Rush Pink}

Rush Pink, a perennial composite, is found only in wet areas in the province: along the South Saskatchewan and Frenchman River valleys (Figure 5). This species looks very similar to the two native species of

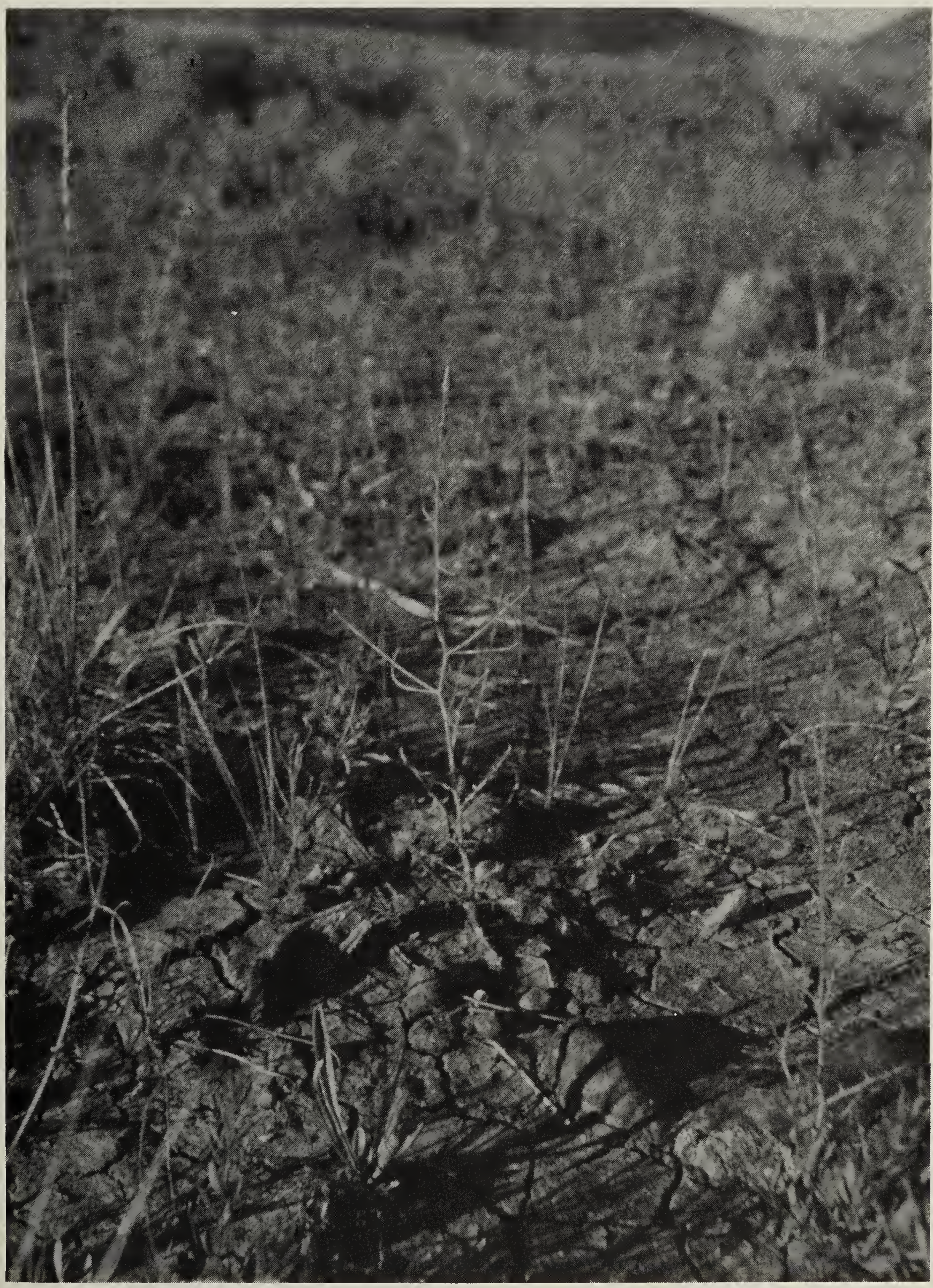

Figure 6. Rush Pink (Stephanomeria runcinata). 
Skeletonweeds (Lygodesmia juncea and $L$. rostrata). All three species have mint green stems which exude milky juice, scale-like upper leaves and flowers with pink rays. The key to identifying Rush Pink is that the lower leaves are somewhat broader and toothed (Figure 6) than those of the Skeletonweeds, which have linear, untoothed leaves. Three of the five new populations of Rush Pink occurred in the same habitat as Western Hawk's-beard and are discussed in the previous section. The other Rush Pink populations were associated with Cryptantha celosioides. C. celosioides is listed as being a rare Saskatchewan plant in Harms et al. (1992). Until recently, it was considered to be a variety of Clustered Oreocarya (C. nubigena). The two species can be distinguished by the basal leaves. C. celsioides has egg-shaped basal leaves that are 5 to $8 \mathrm{~mm}$ wide while those of Clustered Oreocarya are narrower.

Rush Pink was located near the old Herbert Ferry (LSD9 S11 T20 R11 W3) on 22 May 1996. Approximately 50 individuals were found on a steep, eroding, loamy, south-facing slope of a butte near the river. Clustered Oreocarya was found on the top of this butte.

The fifth new population of Rush Pink was encountered on 28 May
1996, southwest of the Matador Field Station (S9 T20 R13 W3). Thirty individuals were found on the southfacing, sandy clay loam slopes of a coulee. Clustered Oreocarya was found on the same slope.

\section{Conclusion}

The South Saskatchewan River valley is a picturesque, biologically diverse area in our province. In addition to the many rare plants found here, the valley is home to deer, foxes, coyotes, cougars, birds of prey and songbirds. They are attracted by the abundance of water and lush vegetation. Unfortunately, the rough topography and lack of access points make the valley somewhat difficult to explore. Doubtless, there are many more populations of rare plants living there, waiting to be discovered.

\section{Acknowledgements}

I would like to thank the Prairie Ecosystem Study and the Heritage Foundation for their financial support of my research. Special thanks to Dr. Vernon Harms for his assistance in preparing this paper.

1. MOSS, E.H. 1983. Flora of Alberta. Second edition. University of Toronto Press, Toronto.

2. HARMS, V.L., P.A. RYAN and J.A. HARALDSON. 1992. The rare and endangered native vascular plants of Saskatchewan. University of Saskatchewan, Saskatoon.

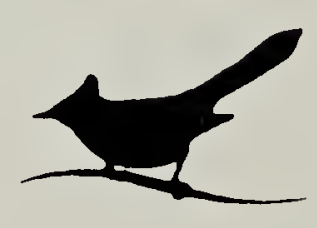

The population of Loggerhead Shrikes in Alberta was recently estimated to be close to 5,000 pairs (Bjorge and Prescott, Canadian Field Naturalist). 